\title{
Proposal for a New Norwegian Code of Criminal Procedure - A Summary of NOU 2016: 24
}

The following text is the summary of the proposal for a new criminal procedure code for Norway, NOU 2016: 24 (Norwegian Official Report). The proposal was submitted to the government on the 3rd of November this year, from the commission consisting of Runar Torgersen (leader), Lars Groth, Kristin Fagerheim Hammervik, Hans Petter Jahre, Erik Keiserud, Torunn E. Kvisberg, Tor Langbach, Marianne Lie, Jon Petter Rui, Trond Eirik Schea, Inger Marie Sunde and Ida Melbo Øystese (secretary: Anders Løvlie, Esben Kyhring, Sarah Rytterager and Nils Gunnar Skretting). The English summary is the commison's own summary (Chapter 3 of the report), translated by Knut Engedal and included in NOU 2016: 24, appendix 4. The publication of the summary in BJCLCJ is approved by the commission and the Ministry of Justice and Public Security. The entire proposal can be downloaded from https://www.regjeringen.no/no/dokumenter/nou-2016-24/ id2517932/.

\section{Summary}

\subsection{Draft legislation, mandate and summary (Part I of the report)}

Chapter 1 of the report contains the Committee's proposal for an Act relating to the Conduct of Criminal Cases (the Criminal Procedure Act), as well as the other legislative amendments proposed by the Committee. The draft new Criminal Procedure Act is not, to the same extent as the current act, structured on the basis of judicial proceedings. Much of the conduct of criminal cases is extrajudicial, and the Criminal Procedure Act is largely an investigation act. It is to a large extent proposed that general regulations be applied across the various stages of the proceedings. The structuring of the legislative proposal and the relationship to other parts of the regulatory framework are discussed in more detail in Chapter 29.

This is an Open-access article distributed under the terms of the Creative Commons Attribution 3.0 Unported License (http://creativecommons.org/licenses/ by/3.0/, permitting all use, distribution, and reproduction in any medium, provided the original work is properly cited. 
Chapter 2 contains an account of the Committee's appointment by Royal Decree on 20 June 2014, as well as its composition, mandate and work.

The mandate stipulates that the Committee shall 'primarily perform a comprehensive assessment of Act of 22 May 1981 No. 25 relating to Judicial Proceedings in Criminal Cases (the Criminal Procedure Act) and submit, in conformity with its assessments, a proposal for a new general act to replace the said act'.

Apart from requiring a general review and a complete structural revision, the mandate highlights a number of key issues. One important issue the Committee has been instructed to examine is whether to facilitate more active intervention from judges, and thereby more efficient and focused proceedings. The said objective also makes it relevant to reconsider the provisions on preparatory proceedings. The Committee has also been instructed to consider provisions on the use of modern technology at all stages of a criminal case, with a view to enhancing legal safeguards, efficiency and confidence in criminal proceedings. One aspect of this issue is the need for audio and video recording during the main hearing and the use of such recordings, if any, in appeal proceedings. The Committee has also been instructed to consider, for purposes of achieving more efficient processing of criminal cases, measures conducive to increasing the number of confession cases and to examine, in this context, whether a plea bargaining arrangement should be introduced. The handling of evidence is a very important aspect of the conduct of criminal cases. Another key priority under the mandate is therefore assessment of the prospects for more comprehensive codification of the evidence provisions.

Other key issues highlighted in the mandate include the scope for using defence counsel and counsel for the aggrieved, limitations to the scope for appeal, the implications of procedural error, right of access to information, right to compensation in connection with prosecution, and mutual assistance between states in criminal cases. The mandate also emphasises, in view of international developments, that a new act should adequately reflect the various obligations of Norway under international law, not least human rights.

The Committee has also been given a free rein to examine other issues. Key issues addressed by the Committee, but not specifically highlighted in the mandate, include, inter alia, the role and independence of the prosecuting authority and the provisions on custody on remand.

Chapter 3 provides a summary of the four main parts of the report: Draft legislation, mandate and summary (Part I), Fundamental premises underpinning reform (Part II), General observations (Part III) and Comments on the Committee's legislative proposal (Part IV). 


\subsection{Fundamental premises underpinning reform (Part II of the report)}

The mandate of the Committee identifies certain fundamental factual and legal premises of importance to the contents of the Criminal Procedure Act.

In Chapter 4, the Committee discusses the present situation with regard to crime and the conduct of criminal cases at all stages. The Committee discusses the premises outlined in the mandate in this regard, as well as the implications of the present situation for the preparation of a new Criminal Procedure Act. The Committee has, in order to shed light on these matters, commissioned a study from Gert Johan Kjelby, LLM PhD, and Lisbeth Fullu Skyberg, MSc, which is discussed in more detail in Sub-chapter 4.3.3. The study is attached as Appendix 2 to the report.

Legal premises of importance to a new Criminal Procedure Act are addressed in Chapter 5 of the report. Apart from the legislative limitations and guidance emanating from the Constitution and international law, this chapter also discusses key principles and fundamental considerations in our procedural tradition.

\subsection{General observations on the Committee's proposal (Part III of the report)}

\subsubsection{Information and communications technology}

The use of information and communications technology in criminal proceedings is repeatedly highlighted in the mandate, in relation to (1) the use of technology by criminals, (2) the use of technology in the administration of criminal proceedings, and (3) audio and video recording of court hearings, as well as judicial and non-judicial taking of evidence. Issues relating to these topics are discussed jointly in Chapter 6.

The Committee proposes, as a main rule, that the proceedings in court hearings be recorded on audio and video; see Sub-chapter 6.5.3.3. The Committee recommends, furthermore, to facilitate playback of recordings of testimony from the court of first instance in the appeal hearing; see Sub-chapter 6.5.4.5. See also Sub-chapter 3.3.3, 3.3.7 and 3.3.9 below.

Financial and administrative implications of the need for conversion, renewal and procurement of administrative processing systems, audio and video recording equipment, etc. are discussed separately in Sub-chapter 28.3. Estimates are also provided as to the time needed to make such changes to existing computer systems as are necessary to enable the act to enter into effect. 


\subsubsection{Introductory provisions. Criminal case participants. Access to information} (Part 1 of the draft legislation)

In Chapter 7, the Committee addresses the scope of the act and its relationship to international law (Chapter 1 of the draft legislation).

It is proposed to retain the scope of the act in the draft, although in simplified form, thus implying that cases concerning 'punishment and other criminal law sanctions' within the meaning of the Penal Code - shall be governed by the Criminal Procedure Act. Furthermore, it is clarified that the act governs assistance to foreign authorities in criminal matters, the processing of civil claims heard as part of criminal cases and the processing of claims for compensation after criminal prosecution.

The Committee proposes that the act shall apply subject to the limitations resulting from the provisions of international law with regard to immunity and jurisdiction. It is not proposed to maintain the general provision in Section 4, Sub-section 1, of the Criminal Procedure Act, stipulating that the act applies subject to such 'limitations as are recognised in international law or which derive from any agreement made with a foreign state, in view of, inter alia, the precedence provision in the Human Rights Act.

Chapter 8 addresses key issues relating to the prosecuting authority (Chapter 2 of the draft legislation), including its organisation, fundamental principles underpinning its activity, distribution of the power to prosecute, etc. Although the mandate does not specifically request examination of the provisions on the prosecuting authority and its activities, the Committee has deemed it appropriate to propose certain changes.

The Committee proposes to formalise and strengthen the prosecuting authority's independence from political authorities. The Committee is of the view that it is important to safeguard the independence of the prosecuting authority through, inter alia, an organisational structure that not only based on practice, but also in formal terms, excludes political interference in individual decisions. Consequently, it is proposed that the King in Council shall not serve as prosecuting authority, and it is proposed to abolish the power held by the King in Council to bring prosecution, as well as to instruct and overrule in individual cases, under prevailing law. Reference is made to the discussion in Sub-chapter 8.2.1. Moreover, the Committee proposes the inclusion of a requirement for 'independent accusation' in Article 96 of the Constitution; see Sub-chapter 8.5.

The draft is based on the prosecuting authority having general responsibility for managing the interest of the State in criminal prosecution. Such responsibility should, as a general premise, be based on a strong presumption that criminal offences shall be prosecuted, and the main rule in the draft is therefore, as at present, that the prosecuting authority has a duty of criminal prosecution. It is, at the same time, proposed that the prosecuting authority shall continue to have discretionary scope for refraining from 
prosecution even though the requirements for prosecution have been met; see Sub-chapters 5.3.1, 8.3.2 and 8.3.3.

The Committee proposes that the new Criminal Procedure Act should also include provisions on distribution of the power to prosecute internally in the prosecuting authority. It is proposed that the power to prosecute shall to some extent be placed lower down in the hierarchy of prosecution than under the current act, primarily by way of an expansion of the power of the prosecuting authority in the police to bring indictment and to make other positive prosecution decisions. It is, at the same time, proposed to leave scope for delegating the prosecution decision to a subordinate level, in both individual cases and through general instructions. The purpose of the proposals is to facilitate a more appropriate division of duties and improved resource utilisation in the prosecuting authority. The Committee would, in this context, like to enable the superior prosecuting authority to focus, to a greater extent than at present, on engaging in training, guidance and supervision of subordinate levels. See Sub-chapters 8.2.2 and 8.4 for additional details.

The Criminal Procedure Act stipulates that the superior prosecuting authority holds a general power to instruct and overrule. It is proposed that this arrangement be continued. One issue discussed by the Committee has been whether and, if applicable, to what extent there should also be a power to instruct and overrule within each level of the prosecuting authority. There is some divergence of opinion as to what is the current state of law on this matter under the current act. The Committee has started out from the premise that the chief of police and the chief prosecutor at the public prosecutor level shall have overall responsibility for the activities of the police district and the public prosecutor district, respectively, including responsibility for quality in the conduct of criminal cases and the use of resources. The Committee is of the view that the chief must also, as part of this, be able to influence the conduct of individual cases. It is the view of the Committee, based on this approach, that there is no reason to make an exemption from general principles of administrative law on the power to instruct and overrule, and the draft seeks to clarify this. Reference is made to Sub-chapter 8.2.6.

Chapter 9 addresses key issues relating to the suspect and defence counsel (Chapter 3 of the draft legislation). The Committee proposes to eliminate the statutory category of the 'person charged'. Rights under the act will be attributed to the 'suspect', who according to the draft is the person subject to investigation or prosecution; see Sub-chapter 9.2. The Committee proposes that the rights and obligations of the suspect be brought together and rendered visible. The presumption of innocence and the protection against self-incrimination are specifically highlighted. The Committee proposes that the protection against self-incrimination shall only apply to natural persons, and not to enterprises; see Sub-chapter 9.3.5. Furthermore, the Committee proposes to expand the right to defence counsel in important respects. Of special importance is a right to defence counsel 
during examination by the police and when the aggrieved person is entitled to counsel; see Sub-chapters 9.4.3.2 and 9.4.3.3.

The role and duties of defence counsel are clarified in the act. The statutory rights are, as a main rule, conferred on all defence counsel. No distinction is made between officially appointed and private defence counsel in other respects than the issue of remuneration. There are diverging opinions in the Committee on the issue of whether the permanent defence counsel arrangement should be expanded to include a larger number of advocates than at present. No specific proposal is made for regulation of the said issue.

Chapter 10 addresses regulation of the role of the aggrieved person and counsel for the aggrieved, as well as the position of surviving relatives and injured persons (Chapter 4 of the draft legislation). The Committee proposes to define the 'aggrieved person', 'surviving relatives' and 'injured persons' in the act. The Committee proposes, as in relation to the suspect, that the rights of the aggrieved persons and surviving relatives be brought together and rendered visible. The rights are predominantly maintained in conformity with current provisions. However, the Committee proposes that the rights be conferred, as a main rule, on all aggrieved persons and surviving relatives, and the concept of special rights for 'the aggrieved person with counsel' and 'surviving relatives with counsel' is not retained. It is nonetheless stipulated that certain rights shall be exercised by counsel for the aggrieved as a professional participant.

The right to counsel for the aggrieved is expanded to include cases involving stalking, robbery and gross bodily injury. It is proposed that the automatic right to counsel for the aggrieved shall be curtailed when such counsel is unnecessary because of the nature of the case and the circumstances of the aggrieved person. Furthermore, the Committee proposes that the court may order several aggrieved persons and surviving relatives to use joint counsel. Besides, the proposal allows for somewhat expanded use of coordinating counsel for the aggrieved. The role and duties of counsel for the aggrieved is clarified in the act and, as with the permanent defence counsel arrangement, there is not a consensus in the Committee on the issue of whether the arrangement should be expanded to include a larger number of advocates than at present.

Chapter 11 addresses regulation of the courts (Chapter 5 of the draft legislation). The provisions on the composition of the courts are maintained, subject to certain changes. The Committee proposes to limit the scope for the district court to comprise one professional judge in cases concerning non-accepted penalty charge notices. The provision shall only apply to cases that cannot result in anything more than the imposition of a fine. Furthermore, it is proposed that the limitation to the powers of deputy judges be eliminated, thus implying that criminal cases can be distributed at the discretion of the chief judge of the court. As far as the court of appeal is concerned, the Committee proposes that lay judges participate in the hearing of all sentencing appeals. The Committee's proposal is otherwise that the standard arrangement in the court of appeal shall, as at 
present, be to have a composite court, comprising three professional judges and four lay judges. No view has been taken on court composition in cases that are currently heard before a jury, since the Committee's mandate specifically states that this issue shall be addressed in a separate legislative effort.

Chapter 12 contains the Committee's general observations on the right of access to information in criminal cases (Chapter 6 of the draft legislation). It is proposed to dedicate a separate chapter to access to information in criminal cases, as well as to significantly restructure the regulatory framework, partly to make the regulations more easily accessible, and partly to enhance predictability for those involved, as well as for individuals who disclose information to the police. The substance of current provisions and practices is largely retained. What information is encompassed by the right of access is defined in the act and labelled the 'case details'. The Committee proposes that the right of access to information shall, as a main rule, encompass all information generated during investigation and hearing of the case. A distinction needs to be made, as under prevailing law, to exclude information that does not form part of the 'case.' The draft does, inter alia, codify the existing practice under which information from informants, etc., is, as a main rule, excluded from the case, and thus from the right of access to information.

The draft regulates the right of access to information for the various criminal case participants and for the general public, respectively, in separate provisions. It is proposed, as at present, that the exemptions from access be linked to the various stages of the proceedings. It is proposed to introduce a provision allowing for somewhat greater access to the case details for the media than under the current act. The right of the general public to access to audio and video recordings from court hearings shall, under the Committee's proposal, be more limited than the right to access to other information in criminal cases. The Committee proposes, in order to reduce the risk of dissemination, that access to such recordings outside the courts be granted as a matter of exception only.

\subsubsection{Evidence (Part 2 of the draft legislation)}

In Chapter 13, the Committee discusses general issues in relation to evidence (Chapters 7 to 12 of the draft legislation). The Committee has accorded the evidence provisions more prominence than in the current act, in terms of both the structuring of the draft legislation and the wording of such provisions. The conduct of criminal cases is principally a matter of gathering, processing and examining evidence, and it is appropriate for the key overarching provisions governing this core duty to be set out jointly at the beginning of the act.

A number of important changes are proposed to the evidence provisions. An absolutely key feature is that the draft largely aims to regulate evidential issues for all partici- 
pants, and at all stages of the proceedings, via general provisions. This offers pedagogic, systematic and structural benefits; see Sub-chapters 13.2, 13.3.3 and 13.3.5 for additional details.

The Committee proposes to codify key elements of the general law of evidence in a separate chapter; see Chapter 7 of the draft legislation and the discussion in Sub-chapter 13.2. The draft includes provisions on the handling of evidence, including, inter alia, on adequate basis for adjudication, adversarial proceedings and the processing of evidence, as well as on the principle of general admissibility of evidence, the responsibility of the court for clarifying the facts of the case, the assessment of evidence and the standard of proof. The Committee sees a pedagogic benefit in such provisions being codified rather than - as at present - largely being taken for granted.

The draft explicitly regulates the duty of the court to check that the evidence presented by the parties is relevant, and also introduces a right to curtail undue presentation of evidence. Presentation of irrelevant and excessive evidence results in prolongation of the proceedings, without any increase in quality, and the proposals seek to better facilitate the focused and efficient conduct of criminal cases; see the discussion in Sub-chapter 13.2.5.1.

It is proposed, in view of the prosecuting authority's burden of proof and the position of the Committee with regard to the adversarial principle, that the responsibility of the court for clarifying the facts of the case, cf. Section 294 of the Criminal Procedure Act, should be specified to make it clear that it shall not be the role of the court to elucidate the case to the detriment of the suspect; see the discussion in Sub-chapter 13.2.5.2.

The Committee's proposal for regulation of the standard of proof is based on the premise that any facts which are to underpin a ruling that imposes criminal liability must be proven beyond any reasonable doubt. This shall apply to all conditions for criminal liability - also subjective culpability and soundness of mind - and also, as the overwhelmingly main rule, to circumstances of importance to sentencing. If there is reasonable doubt, the most favourable facts from the point of view of the suspect must be applied; see the discussion in Sub-chapter 13.2.7.

Chapter 8 of the draft legislation has reorganised the provisions on the barring of evidence when compared to the current act. The Committee has focused on drafting the provisions in conformity with the so-called principles of neutrality. The provisions on the barring of evidence in the draft legislation therefore apply, as a general rule, irrespective of the stage of the case, in relation to any participant, in respect of any item of evidence and to any use of the evidence; see the discussion in Sub-chapter 13.3.3. Such regulation makes the provisions more readily comprehensible and limits the need for reiterations, and the provisions on the barring of evidence clarify, already in their wording, some key interpretational issues that have arisen under the current provisions. Besides, the Committee is of the view that neutrally structured provisions on the barring of evidence 
will, to the extent that these result in a modification of prevailing law, more appropriately reflect the underlying considerations in the conduct of criminal cases. The Committee has, at the same time, discussed the scope of certain specific provisions on the barring of evidence, and maintained and expanded certain exemptions from these in, inter alia, situations in which there is reason to believe that the suspect will be wrongly convicted or subjected to significantly stricter punishment in the absence of such evidence.

Chapter 9 of the draft legislation contains provisions on the duty to testify and exemptions from such duty to testify. The draft predominantly represents, in this regard, a continuation of prevailing law, subject to some modification. The media play an essential role in a democratic society, and protection of the free media should be strengthened. The Committee therefore recommends an expansion of the exemption from the duty to testify for journalists, such as to protect them not only against disclosure of the identity of a source. The media's confidential communications with sources, and the contents of such communications, should be protected as such. Furthermore, the Committee proposes to curtail the scope for encroaching on the media's protection of sources, when compared to prevailing law; see the discussion in Sub-chapter 13.4.3.

In Chapter 10 of the draft legislation, the Committee has brought together a number of regulations on witness testimony, including provisions on summoning witnesses and the suspect for examination by the police and for judicial examination, the conduct of examination, the examination of children and vulnerable persons, witness testimony during the main hearing and the appeal hearing, the recording of testimony and anonymous witnesses. The most important change concerns the scope for using audio and video recordings of testimony from the hearing before the district court during the appeal hearing, cf. Sub-chapters 3.3.1 and 3.3.7. It is proposed that available recordings shall, as a main rule, be played back, in full or partial replacement of oral examination, unless otherwise merited by considerations relating to due clarification of the facts of the case. This arrangement will make proceedings more efficient, without any negative impact on due process protection; see Sub-chapter 6.5.4 for additional details. The Committee also proposes that audio and video recordings may be used for purposes of selecting which appeals to hear; see Sub-chapters 17.3.4 and 20.4.4, cf. also Sub-chapter 3.3.9.

The general position of the Committee is that the right of the suspect to challenge the evidence should be strengthened and embedded in our own legislation and tradition, as opposed to exclusively relying on minimum rights deriving from the European Convention on Human Rights; see the discussion in Sub-chapter 13.5.2. The Committee would like to retain the main features of the facilitated examination arrangement, but it should be modified somewhat, both to make the regulation more readily comprehensible and to attend to the rights of the suspect in an adequate manner. The draft legislation is structured in such a way that the regulation will not impair the protection of children's interests during the conduct of criminal cases; see Sub-chapter 13.5.3. 
Chapter 11 of the draft legislation contains rules on the use of experts in criminal cases; see the discussion in Sub-chapter 13.6. Light needs to be shed on numerous and manifold circumstances in criminal cases, and special expertise may be required to fully establish the facts of the case. 'Experts' are defined in the draft as persons with special knowledge and experience, and it is specified that such knowledge shall be 'verifiable'. This implies that the statute requires experts to only issue opinions within the scope of their professional expertise. This accommodates a key criticism against evidence in the form of expert opinions, i.e. that experts have also been mandated to express a view on whether legal conditions are met.

In order to safeguard the quality of opinions, as well as to inspire confidence that expert opinions are exclusively based on professional expertise, the independence requirement for experts is made stricter. The draft legislation defines formalised procedures for clarifying, at an early stage, whether the expert has any ties of relevance to his or her appointment as expert. The Committee emphasises the importance of vigilance in the drafting of the mandate and the subsequent follow-up thereof during the proceedings.

The Committee is of the view that it would be appropriate to continue the arrangement under which the Norwegian Board of Forensic Medicine reviews medical opinions within key areas of specialisation, and also allows for the establishment of review schemes for other types of expertise. The Committee is of the view that the main rule should still be that the suspect, with his or her defence counsel, relies on the court-appointed, or alternatively prosecution-engaged, expert and contributes to ensuring that the mandate covers the issues on which the defence believes that light should be shed. The Committee is, at the same time, of the view that court-appointed and party-engaged experts should, to a greater extent than at present, be accorded the same status, thus implying, inter alia, that privately engaged experts must be ensured good working conditions in court. The use of experts by the prosecuting authority is clarified and formalised.

Sub-chapter 13.7 addresses the Committee's proposed provisions on the securing of evidence in court, which essentially maintain the substantive scope for taking of evidence under prevailing law, although in a separate chapter. The taking of evidence with a view to the inspection of objects and the examination of individuals are regulated jointly; see Chapter 12 of the draft legislation.

\subsubsection{Investigation and coercive measures (Part 3 of the draft legislation)}

Chapter 14 contains the Committee's discussion of the provisions on investigation and coercive measures (Chapters 13 to 23 of the draft legislation).

The investigation provisions are not specifically addressed in the mandate, but the Committee proposes clarification in several respects, including, inter alia, with regard to 
the investigation concept, the division of responsibilities and the conditions for investigation.

As far as coercive measures are concerned, the perspective is that the Committee is at liberty to propose changes, although it is assumed in the mandate that the regulation of such interventions will in all principal respects be adequate in the wake of the latest revisions to the rules, prepared independently of the Criminal Procedure Committee. This Committee has not, against said background, engaged in any detailed assessment with a view to potentially fundamental changes to the methods available to the police, but certain coercive measures are addressed in more detail. Besides, the Committee proposes significant restructuring and simplification of the regulatory framework.

General provisions on investigation are addressed in Sub-chapter 14.2 (Chapter 13 of the draft legislation). The Committee has, inter alia, considered what should be the purpose of investigation under the act. The general rule should be, in line with the purpose of criminal procedure, that the investigation shall uncover information of relevance to the question of prosecution, preparing the court's deliberation of the issues of guilt and sanctions, and ensuring the enforcement of punishments and other sanctions. It is nonetheless desirable, for various reasons, to maintain the scope for investigation for other purposes as well, including investigation with a view to avert criminal acts, shedding light on cases concerning measures against young offenders under the Child Welfare Act, as well as clarifying the course of events and causal relationships in respect of fires, accidents and deaths. In addition, the draft allows for investigation in cases involving disappearance, irrespective of whether there is reason to assume that such disappearance was caused by a criminal act.

The draft maintains 'reasonable grounds' as the general criterion for when an investigation can and shall be commenced. The proposed draft specifies, in order to clarify that this is a matter of discretionary assessment, as well as the scope of such assessment, certain key considerations of particular relevance in making the said assessment. The specification of such considerations also aims to highlight that the criterion 'reasonable grounds' allows scope for discretionary assessments. See Sub-chapter 14.2.3 for additional details.

The draft clarifies that overall responsibility for the investigation lies with the prosecuting authority. It is specified, at the same time, that such responsibility also implies a duty to actively lead the investigation such as to ensure that it is focused on serving its purpose and that fundamental implementation requirements are complied with. In addition to maintaining the current requirements of objectivity, due consideration and swiftness, the draft emphasises that the investigation shall be planned and focused. Besides, it is stipulated, as a general and explicit requirement, that the investigation shall be documented, such as to ensure verifiability. See Sub-chapter 14.2.4. 
Sub-chapter 14.3 contains general observations on the provisions on coercive measures (Chapters 14 to 23 of the draft legislation).

The Committee proposes joint regulation of basic conditions and joint provisions for all coercive measures (Chapter 14 of the draft legislation). The current provisions are characterised by a number of identical or similar regulations for the various coercive measures, and there is an evident need for making the provisions clearer and more readily comprehensible. Besides, joint regulation of basic conditions and joint provisions serves to clarify the general premises and the need for exceptions.

Three basic conditions will need to be met in respect of all coercive measures, unless otherwise stipulated. Firstly, 'just cause' is proposed as the general condition with regard to the level of suspicion. Secondly, it is proposed that such suspicion must as a general rule pertain to a 'criminal act'. This implies that no elevated crime threshold is proposed, and that any such elevated threshold must be stipulated in relation to each coercive measure. Thirdly, it is proposed, as a basic condition, that the intervention must be 'necessary and proportionate'.

The scope for using coercive measures for preventive purposes is also regulated in the chapter on basic conditions and joint provisions, with the stipulation of suitably modified requirements as far as the conditions relating to 'suspicion' and 'criminal act' are concerned. Furthermore, joint provisions are proposed on decision-making powers, requirements applicable to the requests and decisions of the prosecuting authority, as well as implementation, non-disclosure orders, duration, reporting and notification.

In Sub-chapter 14.4, the Committee discusses coercive measures that curtail liberty, in the form of a duty to report periodically to the police, as well as arrest and custody, etc. (Chapter 15 of the draft legislation). Special attention is devoted to the use of custody on remand, because deprivation of liberty prior to any judgment is a serious intervention, and because remand practice has for a long time been criticised from both domestic and international quarters. One of the main objectives of the Committee's proposal is to emphasise the principle of minimum intervention in the choice between various restrictions on liberty, and the importance of the principle of proportionality, in general and in relation to custody in particular.

It is proposed that the conditions for using custody be made stricter in several respects. The use of custody because of a risk of escape or a risk of tampering with evidence can only be decided, under the Committee's proposal, when the suspicion concerns the violation of penal provisions punishable pursuant to statute by imprisonment for a term of 2 years or more. Custody can only be used when the risk of tampering with evidence represents a considerable risk in terms of the prospects for criminal prosecution. A risk that the suspect modifies his or her own testimony cannot be taken into consideration for purposes of such assessment. Furthermore, it is proposed that a risk of tampering with evidence cannot result in custody being used for more than 3 months. It is proposed that 
restrictions in the form of the suspect being refused any form of interaction with other inmates be limited to cases in which this is 'of material importance to the investigation', and these cannot, according to the draft, be decided for more than 2 weeks at a time and can only be extended as a matter of 'exception'. Isolation is excluded for suspects below the age of 18 years. The use of custody due to a risk of new criminal acts can, according to the legislative proposal, only be decided to prevent the suspect from committing new offences that pose a risk to anyone's life, health or liberty, or in case of repeated offences that are of a socially detrimental or especially troublesome nature.

It is proposed to retain the arrangement for the use of bail and other forms of collateral. The desire to avoid 'class justice' is a relevant consideration, but the Committee is of the view that this cannot take precedence over the principle of minimum intervention in potential cases where the furnishing of collateral is sufficient to attend to criminal prosecution considerations. It is proposed to grant the prosecuting authority the power to decide that an agreement for the furnishing of collateral shall be concluded. It is, furthermore, proposed to allow for electronic control as an alternative, not least to the use of custody.

Sub-chapter 14.5 addresses the provisions on social inquiry and forensic psychiatric observation (Chapter 16 of the draft legislation). The Committee proposes a continuation of the present arrangement, but brings together and simplifies a number of regulations that are currently spread across the act. The draft is based on the premise that the prosecuting authority may initiate a social inquiry in any case, and the Committee recommends that the Norwegian Correctional Service conducts the social inquiry in all cases.

As far as concerns forensic psychiatric observation, the Committee has followed up a number of the recommendations made in Official Norwegian Report NOU 2014: 10 by the committee appointed to examine the criminal insanity provisions, including its proposal that one should in this field normally appoint two experts, one of whom shall be an approved specialist. See also the general regulations on the use of experts in Chapter 11 of the draft. The Committee is of the view that there should, given the importance of such observation and inquiry, in addition to forensic psychiatric observation be scope for subjecting the suspect to involuntary initial forensic observation and social inquiry.

In Sub-chapter 14.6, the Committee proposes to bring the provisions on body search and identification measures together in a separate chapter (Chapter 17 of the draft legislation). The regulation predominantly represents a continuation of prevailing law. However, the Committee is of the view that there should be scope for gathering DNA evidence without first having to establish a strong basis for suspicion by using other evidence.

Sub-chapter 14.7 contains the Committee's discussion of the provisions on search and inspection of objects (Chapter 18 of the draft legislation). Prevailing law is continued in the main, subject to some modification and restructuring, including, inter alia, that the type of close inspection of objects which is currently regulated in the provisions on in- 
quiry will be regulated in the same chapter as the search for objects. Searches directed at the suspect and third parties, respectively, are regulated by separate provisions. Searches intervening in the innermost sphere of privacy - in the form of personal search and home search, etc. - are, in their part, regulated in the same provision.

Sub-chapter 14.8 addresses the Committee's proposal for regulation of seizure and surrender orders (Chapter 19 of the draft legislation). The Committee's proposal for the structuring of the statutory provisions on the barring of evidence implies that there is no longer any need for separate regulation with regard to non-seizable materials; see Sub-chapter 13.3.5, cf. 13.3.3, on the principle of neutrality underpinning the provisions on the barring of evidence in the draft legislation. Large seizures, not least of digitally stored materials, have mounted. This poses, in such cases, practical challenges for the judicial control of compliance in relation to non-seizable materials. The Committee examines certain fundamental aspects of this issue, and recommends that more detailed provisions on how to handle such cases in practice be laid down in the form of administrative regulations.

Sub-chapter 14.9 addresses the Committee's proposal for provisions on intervention in communications, etc. (Chapter 20 of the draft legislation). The chapter is predominantly a continuation of the current provisions on various forms of monitoring of communication facilities and communications, covert audio surveillance and computer surveillance.

In Sub-chapter 14.10, the Committee presents its assessments in relation to observing, controlling and influencing measures (Chapter 21 of the draft legislation). The proposal encompasses codification of methods that are currently used on non-statutory grounds. These include undercover work, infiltration, influencing the course of events and provoking evidence. Human rights - and partly also domestic - developments towards stricter requirements as to statutory authorisation, also in the field of criminal procedure, suggest that these methods should be codified, although not in detail. It is proposed that such methods be regulated along with the already statutory methods of technological tracking, concealed camera surveillance, as well as audio surveillance and recording of conversations with the consent of a party to such conversations.

Sub-chapter 14.11 contains the general observations of the Committee on the proposal concerning intervention in the assets of the suspect (Chapter 22 of the draft legislation), which brings the provisions on charges on, and freezing of, assets together in one chapter.

Sub-chapter 14.12 addresses the regulation of restraining orders to ban contact and visits (Chapter 23 of the draft legislation). 


\subsubsection{International cooperation (Part 4 of the draft legislation)}

Chapter 15 discusses the Committee's proposal for the joint regulation of various issues relating to international cooperation in criminal matters (Chapters 24 to 27 of the draft legislation). Collaboration with foreign authorities has in recent years become an important and - in certain areas - regular part of the conduct of criminal cases. The Committee is of the view that this should be reflected in a new Criminal Procedure Act.

The domestic regulation of international cooperation in criminal matters is rather patchy under current statutes and administrative regulations. Besides, Norway has acceded to a number of international treaties on mutual assistance and other cooperation in criminal cases, which also affect provisions in this area and make it challenging to get an overview of these. Consequently, there is a need for bringing together the said provisions and restructuring these to make them clearer and more readily comprehensible. However, the Committee is of the view that there is little need for provisions allowing additional scope for cooperation, as the current provisions allow for extensive cross-border cooperation. In terms of substance, the draft is therefore predominantly in conformity with prevailing law. It regulates, in addition to mutual assistance in criminal cases, the transfer of criminal cases, as well as more specialised provisions on cooperation on the boarding of vessels and on special operations outside Norwegian territorial waters, etc.

The Committee has opted for excluding the provisions on the detention, extradition and handover of individuals for criminal prosecution or the execution of sentences, as well as the transfer of convicted individuals, from the draft new Criminal Procedure Act; see Sub-chapter 15.3.1.

\subsubsection{Prosecution decisions (Part 5 of the draft legislation)}

Chapter 16 discusses the Committee's proposed provisions on prosecution decisions (Chapters 28 and 29 of the draft legislation). The draft is largely a continuation of prevailing law as far as concerns the various types of prosecution decisions and the applicable conditions.

The Committee proposes the codification of a relative time limit for making prosecution decisions, which corresponds to the requirement for decisions to be made within a reasonable period of time, cf. Article 95 of the Constitution and Article 6(1) of the European Convention on Human Rights. In order to provide the suspect with an effective judicial remedy against failure to observe the time limit, the draft legislation establishes a judicial review arrangement under which the suspect may after 1 year and 6 months bring the question of whether the case is being conducted with sufficient swiftness before the court. If the court finds that a continuation of proceedings - all circumstances tak- 
en into consideration - would be unreasonable, the court may stipulate a time limit for reaching a decision on the issue of prosecution. Such time limit may be extended upon request. If the prosecuting authority fails to observe the time limit, the proceedings shall be deemed to have been discontinued, and further prosecution of the same matter shall be barred. One member of the Committee does not endorse the proposed judicial review arrangement; see Sub-chapter 16.2.

There should as a main rule, as mentioned in Sub-chapter 3.3.2, be a strong presumption that criminal acts shall be prosecuted. It must, at the same time, be acknowledged that there may be a number of different reasons why prosecution should nonetheless not take place in any given case. The principle of discretionary power to waive prosecution, and the considerations underpinning such principle, implies that the Committee is of the view that the prosecuting authority should have relatively broad discretionary scope for considering whether prosecution is appropriate.

It is proposed that the provisions in the current act on waiver of prosecution be retained. It is furthermore proposed to allow general scope for the prosecuting authority to decide discontinuance of proceedings in cases where prosecution is not in the public interest. It follows clearly from the draft and the comments that what needs to be demonstrated is the absence of a public interest in criminal prosecution. The draft legislation also lists typical scenarios to provide guidance on what situations may give rise to a discontinuation of proceedings, as well as which considerations the prosecuting authority should take into account. This is, in other words, a discretionary power to discontinue proceedings, subject to clear guidelines. The regulation also implies that the prosecuting authority may to some extent decide to discontinue proceedings on grounds of capacity, including, inter alia, as part of the necessary prioritisation of resources.

Sub-chapter 16.8 discusses the Committee's proposal for formalisation of the scope of the prosecuting authority for engaging in plea bargaining under prevailing law, i.e. that the prosecuting authority may make a commitment to the suspect that it will request the courts to hand down a specific sentence. The draft makes such commitments conditional upon the suspect confessing or otherwise disclosing information of importance to his or her own case. It is proposed, in order to ensure a certain element of predictability for the suspect, that the court shall only have the power to hand down a stricter sentence than is reflected in the commitment if it 'seems evident that the specific sanctions imposed would otherwise be incorrect' This provision does not prevent the court from correcting errors when there are sufficient grounds for doing so, but the court is required to take into account that the prosecuting authority is often best placed to assess the significance of the cooperation of the suspect. No amendments are proposed to Section 78, letter f, of the Penal Code on reduced sentence upon confession, etc. The Committee nonetheless assumes that a formalised plea bargaining arrangement may in itself serve to increase the 
number of confession cases and, more generally, give the suspect an incentive to contribute information that may simplify the conduct of the case.

\subsubsection{General provisions on court proceedings and court rulings (Part 6 of the draft legislation)}

Chapter 17 addresses general provisions on court proceedings, including case management, consolidation and splitting of cases, court hearings, court rulings, absence, etc. (Chapters 30 to 33 of the draft legislation). It is proposed that provisions on court records, the audio and video recording of court proceedings and the use of remote hearings and remote examination be brought together in the Courts of Justice Act.

The Committee is of the view that the court should, as a general rule, have overall responsibility for case management, especially with a view to achieving sound, focused and efficient proceedings. The Committee sees no fundamental reasons why the court should not assume such a role, provided that case management is not exercised in a manner that may impair confidence in the independence or objectivity of the court. The court should, as part of its case management, be able to call upon the parties to provide clarifications, stipulate time limits for the pleadings of the parties and make necessary decisions. The Committee's general discussion of the responsibility of the court for case management can be found in Sub-chapter 17.1.3.

The draft includes provisions on splitting of the proceedings and the ruling. The provisions are largely a continuation of prevailing law, whilst at the same time expanding the scope of the court for ruling on parts of the question of guilt. It also allows for appealing partial rulings, but only with the consent of the court, when it is appropriate out of consideration for the further conduct of the case. It is assumed that it may be of particular relevance to exercise the right of appeal in cases that raise difficult legal issues which it would be appropriate to get clarified by the courts above before hearing and ruling on other aspects of the case.

The draft stipulates that court hearings shall be held when required by statute or decided by the court. Apart from main hearings, appeal hearings and certain other instances in which court hearings are mandatory, it will thus be up to the court to decide whether rulings shall be rendered on the basis of written or oral proceedings. The Committee has concluded that the key factor is in most cases not whether the proceedings are conducted orally or in writing, but whether the court ensures that there is a sound basis for adjudication, including, inter alia, that the right of the parties to challenge evidence and legal arguments is observed.

It is proposed that the scope for using remote hearings and remote examination be regulated jointly for civil cases and criminal cases in the Courts of Justice Act. The Commit- 
tee is of the view that the main rule under such statute should be that parties, witnesses, experts and others should be able to participate in court hearings or render testimony before the court by way of remote hearing technology when reasonable and appropriate. Any exceptions from this main rule are what would need to be justified, and such exceptions are what would need to be specifically regulated. It is of special relevance to make such exceptions with regard to the suspect's attendance of the main hearing and the appeal hearing, as well as with regard to court hearings in relation to custody on remand. Reference is made to the explanations and assessments of the Committee in Sub-chapter 6.4.5.

The Committee proposes extensive audio and video recording of the proceedings during court hearings, including of the testimony rendered by parties, witnesses and experts. It is proposed that joint provisions for civil cases and criminal cases be included in the Courts of Justice Act in this regard. Reference is made to Sub-chapter 6.5.3. The scope for making use of such recording during appeal proceedings, etc. is discussed in further detail in Sub-chapter 6.5.4, cf. also Sub-chapters 3.3.1, 3.3.3 and 3.3.9.

The draft proposes that court rulings be rendered in the form of either judgments or decisions. It is not proposed to maintain the distinction made under the current act between court orders and decisions. Such a classification into various ruling categories will, irrespective of how it is implemented, be fairly arbitrary, and the categories will encompass rulings that are very different in nature. Consequently, the distinction is unsuitable as a criterion for miscellaneous legal effects. Issues relating to the manner in which rulings are rendered, requirements as to the contents of rulings, as well as the scope for reversal and review, etc., can readily be regulated directly, and hence the distinction between court orders and decisions is superfluous.

It is proposed that the current provisions on the basis for court rulings be maintained in their main aspects. Consequently, any ruling following a main hearing or appeal hearing shall be rendered on the basis of the proceedings in such hearing, whilst other rulings shall, as a main rule, be rendered on the basis of the case details, following written or oral proceedings. Certain exceptions from such main rule are proposed with regard to the scope of the appeal court for basing its ruling on factual aspects of the judgment of the subordinate court which are not disputed, and with regard to the basis for denying to hear an appeal in respect of the assessment of evidence under the question of guilt and in respect of the specific sanctions imposed. See Sub-chapter 17.3.

The Committee proposes, furthermore, certain changes to the provisions on the court's reliance on the claims and submissions, etc., of the parties, including the relationship between the indictment and the judgment. The proposals must be considered on the basis of the Committee's position with regard to the importance that should be accorded to the adversarial principle in the new Criminal Procedure Act. No changes are proposed as far as concerns the scope of the court for deviating from the description of the facts in the 
indictment. As under the current act, the court shall not be able to adjudicate any other matter than that addressed in the indictment, but it shall not be bound by the specific details in the indictment with regard to time, place and other circumstances. However, it is proposed that the court's scope for applying legal rules to such facts be restricted. A majority of the Committee members attach considerable weight to the perspective that the indictment's specification of the facts of the case, together with its legal characterisation of these, offers the best indication of what the prosecuting authority has chosen to bring before the court for adjudication. Hence, the majority finds that it conforms best with the adversarial principle, and the considerations underpinning such principle, for the court to be, in principle, bound by such application of legal rules to the facts of the case as is specified in the indictment, although with scope for deviating from such application unless opposed by the prosecuting authority. The minority is of the view that such a solution is in conflict with the principle that the court has independent responsibility for the application of law, and does instead propose to take the approach that the identity of the matter changes if the court needs to base its ruling on other material facts than those described in the wording of the indictment, and also if the new application of legal rules to the facts of the case results in the legal nature of the matter being materially different from that outlined in the indictment. Reference is made to the discussions of the Committee in Sub-chapter 17.6.

The Committee proposes, moreover, that the court shall not be able to adjudicate other claims than those brought by the prosecuting authority. The Committee is of the view that the current regime, under which the court may freely include confiscation and certain other claims in the sentence, irrespective of whether such claims have been brought, is contrary to the adversarial principle, and serves to make proceedings inquisitorial in nature. Besides, the Committee is of the view that there is no practical need for the court to be able to adjudicate claims of its own accord. See Sub-chapter 17.6.5 for further details.

Otherwise, the Committee is proposing, as a main rule, to retain the principle that the court is not restricted by the specific sanctions moved for by the prosecuting authority. The adversarial principle might also occasion limitations to the leeway open to the court in this regard as well, but the Committee attaches decisive importance to the need for ensuring equal treatment and the importance of our tradition in which the Supreme Court has a special responsibility for determining and developing sanction levels in various respects. A certain modification of this main rule is proposed for cases in which the specific sanctions moved for by the prosecuting authority are based on the outcome of plea bargaining. See Sub-chapters 16.8.5 and 17.6.6.2.

The Committee is of the view that current requirements as to written grounds for legal rulings should predominantly be maintained. The various considerations that are to be attended to by way of written grounds apply, at the same time, to varying degrees, depending on the type of ruling. The Committee is therefore of the view that the require- 
ments as to grounds are best regulated by way of a relative standard. One aim is to make the court's specification of grounds more focused than under current practice. Audio and video recording of the proceedings, as proposed by the Committee, will reduce the need for using the presentation of grounds in the judgment to ensure verifiability with regard to the presentation of evidence, and thus the grounds can be more focused on the assessments of the court with regard to the crux of the matter. The requirements as to grounds should to a greater extent reflect the roles and functions of the various courts.

\subsubsection{The conduct of the criminal claim before the district court (Part 7 of the draft legislation)}

Chapter 18 presents the Committee's proposal for regulation of the conduct of the criminal claim before the district court. The relevant provisions cover three chapters: preparing for the main hearing (Chapter 34 of the draft legislation), the main hearing (Chapter 35 of the draft legislation) and simplified proceedings (Chapter 36 of the draft legislation).

The vast majority of criminal cases are small and simple, and the Committee is of the view that one should therefore, as a main rule, not propose more comprehensive preparatory proceedings than are implied by practice under the current act. The legislation must, at the same time, accommodate cases which are broader in scope or more complex, and which may merit more time and resources being devoted to planning and clarification prior to the main hearing.

The draft is, against this background, based on the premise that the preparatory proceedings in ordinary cases shall, generally speaking, be conducted in the same manner as under prevailing law. However, it is proposed to have flexible provisions that allow for additional preparatory proceedings whenever needed; see Chapter 34 of the draft legislation.

One innovation is that defence counsel shall, after having received the documentation from the prosecuting authority, normally file a reply, which shall specify what parts of the factual and legal aspects of the case the defence deems to be in dispute, which evidence the defence will present, whether additional investigative steps are requested, etc. The purpose is to ensure that important clarifications which may simplify the further proceedings take place as early as possible. The duty of defence counsel to file a reply must be considered in view of the suspect's protection against involuntary self-incrimination and the scope of defence counsel's duties.

In certain cases, which are typically of a certain magnitude or complexity, the indictment's specification of the matter brought before the court by the prosecuting authority may offer the suspect limited prospects for preparing his or her defence. The Committee is nonetheless not proposing any changes to the requirements applicable to the indict- 
ment, because it must as a general rule be deemed appropriate for the indictment to be focused and brief. It is instead proposed, in order to accommodate the suspect's need for more detailed information concerning the accusation, to introduce a provision to the effect that the prosecuting authority shall in certain cases, of its own volition, prepare a written account of the case.

The Committee is of the view, as mentioned in Sub-chapter 3.3.7, that the court should generally have an overall responsibility for managing the case in order to, inter alia, ensure planned and focused proceedings. The need for case management is particularly acute during the preparatory proceedings, and the Committee proposes an explicit regulation of the court's case management duty at this stage, including a duty to plan the further proceedings. The requirement for planned proceedings should in principle apply to all cases, but in small and simple cases there will rarely be a need for any formalised plan. This is reflected in the draft.

The draft provides the court with broad scope, during the preparatory proceedings, for making necessary decisions concerning the further conduct of the case, including issues of relevance to the conduct of the main hearing, such as the scope of the presentation of evidence, etc. Decisions during the preparatory proceedings may, according to the draft, be made on the basis of written or oral proceedings, depending on what the court deems necessary to ensure a sound basis for adjudication, cf. Sub-chapter 18.1.6

The draft provides the court with a number of mechanisms for preparatory proceedings, which may be used whenever needed in any given case. It is thus proposed that the court may decide to convene a preparatory court hearing, and that such hearing may be held with only the professional participants in attendance, when it is not necessary for the indicted persons, the aggrieved persons or surviving relatives to be present. It is proposed that the scope of the court for ordering the prosecuting authority to submit a written account of the case be continued, subject to certain minor modifications. It is proposed, moreover, that the court be given scope for calling upon the parties to prepare a joint presentation of the case to clarify which parts of the factual aspects of the case are agreed. The court may, according to the proposal, rely on such a joint presentation of the case, alongside the other evidence in the case. The court may also stipulate a time limit for the submission of closing statements.

The Committee has considered whether the court should, to a greater extent than under the current act, have access to the case documents, which in the draft are referred to as the 'case details'. A majority of the Committee members are of the view that the court should, in principle, have unrestricted access to the case details, both for use during the preparatory proceedings and in the subsequent conduct of the case. The majority believes that it is important for the court - in order to engage in case management, to conduct preparatory proceedings, as well as to monitor and check the presentation of evidence - not to have less access to information than the parties. The position of the majority 
implies no change to the principle that the court may only base its ruling on information that has been presented as evidence in the main hearing or appeal hearing. A minority of the Committee members are of the view that the court should not have access to case information to any greater extent than is implied by prevailing law. The position of the minority is primarily motivated by the its view that the court should not have access to statements made to the police and other information that have not and will not be presented as evidence in the case, as there may in such circumstances be a risk that the court will, deliberately or inadvertently, attach weight to information that has not been subjected to presentation as evidence and adversarial proceedings. See Sub-chapter 17.4 for further details on this issue.

The Committee's proposal for provisions on the main hearing before the district court are structured somewhat differently from the corresponding provisions under the Criminal Procedure Act; see Chapter 35 of the draft legislation and Sub-chapter 18.2. The provisions primarily regulate the sequencing of the main hearing. Provisions on, for example, attendance by the indicted person, the reading of statements made to the police and the duty of the court to clarify the facts of the case, are found in other chapters, in line with the structure of the draft legislation. Another new feature is that the chapter on the main hearing contains a separate provision on case management and allows, to some extent, for written presentation of evidence.

The provisions on judgment based on a plea of guilty - termed judgment based on 'simplified proceedings' in the terminology of the draft legislation - are found in Chapter 36 of the draft legislation. The provisions are predominantly a continuation of the current arrangement, with the difference that it is no longer a condition for such proceedings that the suspect has consented; see the discussion in Sub-chapter 18.3.

\subsubsection{Appeal (Part 8 of the draft legislation)}

Chapter 19 provides a separate discussion of various types of procedural error and their effects. The chapter examines, inter alia, the distinction between so-called absolute and relative errors, which distinction the Committee proposes to retain; see Sub-chapter 19.4.3.

In Chapter 20, the Committee discusses general issues in relation to appeal (Chapters 37 to 39 of the draft legislation). Major structural changes to the regulatory framework are proposed. It is proposed, in order to facilitate more focused appeal proceedings, to introduce stricter requirements with regard to the contents of the notice of appeal than under prevailing law. Furthermore, the Committee proposes changing the provisions on the filing of the notice of appeal, with such notice being filed with the court that rendered 
the ruling, and it is proposed to introduce statutory provisions on time limits for the submission of supporting documentation.

A key reform proposal is to allow for reusing the presentation of evidence that took place before the district court. The Committee proposes extensive audio and video recording of the proceedings in court hearings, including recoding of the testimony of parties, witnesses and experts; see Sub-chapter 6.5.3 for further details on this. It is proposed that recordings from the proceedings before the district court may be played back before the court of appeal instead of, or as a supplement to, direct presentation of witness testimony. See Sub-chapter 6.5.4 for further details on the scope for using the recordings during appeal proceedings, etc., cf. also Sub-chapters 3.3.1, 3.3.3 and 3.3.7.

The Committee has discussed whether there should be a general requirement for selectivity as to whether an appeal shall be heard by the court of appeal. A majority of the Committee members are proposing to abolish the unconditional right to appeal hearing of the so-called six-year cases. It is proposed that all appeals shall, as a main rule, be screened on the basis of a general criterion to determine whether these shall be heard by the court of appeal. There shall be a presumption that an appeal filed in respect of a judgment will be heard, although with scope for denying to hear, on their merits, appeals that clearly cannot succeed. The consent arrangement for 'minor cases' will be continued in its present version. The minority proposes to retain the arrangement with an unconditional right to an appeal hearing for certain cases, in modified form. See Sub-chapter 20.4.4.3.

The Committee has considered solutions that may serve to make the appeal proceedings more efficient and focused, without impairing the scope for sound adjudication of the case. The Committee proposes to allow for the written processing of all appeals over judgments before the court of appeal, when the parties consent to it or the court finds that such procedural format is obviously appropriate. As far as oral appeal hearings are concerned, the Committee proposes a general provision to the effect that the appellant is, as a main rule, responsible for the initial presentation of the case before the court. See Sub-chapter 20.4.6 for further details.

The Committee has concluded that the provisions on the conduct of appeals before the Supreme Court should predominantly remain the same as under prevailing law. However, certain modifications are proposed; see Sub-chapter 20.4.10.2.

\subsubsection{Enforcement and reopening (Part 9 of the draft legislation)}

Chapter 21 contains the Committee's general assessments of the enforcement provisions (Chapter 40 of the draft legislation).

The Committee proposes to abolish the arrangement for a specific enforcement order from the prosecuting authority following a final and binding judgment, because there are 
by then no further prosecution duties to perform. Otherwise, it is predominantly proposed that the substance of the current provisions be retained, although with a different structure.

Chapter 22 addresses the provisions on reopening (Chapter 41 of the draft legislation). The Committee recommends that the current provisions on reopening be predominantly retained as far as their substance is concerned, and that the issue of reopening be resolved, as at present, by the Commission for the Reopening of Criminal Cases. However, the Committee is of the view that there is a need for fairly comprehensive structural revision to make the provisions on reopening and the proceedings before the Commission more readily comprehensible.

The judicial remedies of appeal and reopening are at present partly overlapping, inasmuch as the prosecuting authority may appeal in favour of the convicted person, irrespective of any time limit for the filing of appeals. The Committee is of the view that it would be appropriate to streamline the judicial remedies, with reopening being the only relevant remedy following a final and binding judgment.

The draft legislation stipulates that all rulings rendered in the form of a judgment shall be subject to reopening. This includes - unlike under prevailing law - rulings pertaining to the execution of sentences, because one may otherwise risk having no scope for challenging rulings which suffer from fundamental errors, and which may ultimately result in unlawful deprivation of liberty.

Reopening premised on incorrect application of law currently rests on somewhat uncertain foundations. The draft legislation explicitly allows scope for the reopening of cases for reasons of incorrect application of law in case of material shortcomings with regard to legal authority when it is obvious that one or more key sources of law have been ignored; see Sub-chapter 22.3.6.3.

The Committee is of the view that there should be no time limit for reopening, but recommends stricter reopening conditions for cases that have been finally and bindingly adjudicated for more than 25 years, especially because the evidence situation will after such a long time generally be significantly impaired. The Committee's proposal stipulates that reopening of such cases is subject to 'special circumstances making it doubtful that the judgment is correct'.

The Committee recommends a cautious modification to the intensity of the court's review of the validity of the decisions of the Commission for the Reopening of Criminal Cases. It is proposed that there shall, unlike under prevailing law, be scope for re-examining the Commission's assessment of evidence, but only in 'special cases. The reasoning behind the proposal is that issues addressed in the examination of the matter may be entirely new in the case, thus implying that the question of guilt or the sentencing is examined on a complete basis for the first time before the Commission. It is assumed 
that confidence in the reopening arrangement will be best preserved by giving the courts scope for reviewing, with a certain intensity, the validity of the decisions of the Commission in such situations.

\subsubsection{Military criminal cases (Part 10 of the draft legislation)}

In Chapter 23, the Committee proposes to retain separate provisions for military criminal cases in the Criminal Procedure Act (Chapter 42 of the draft legislation). It is proposed to expand the substantive scope of the regulatory framework, and there shall as a main rule not be made any distinction between acts committed in times of war or peace.

The Committee proposes to retain the military prosecuting authority, directly under the Director of Public Prosecutions. The Director General of Military Prosecutions and the military prosecutors are given the same power to prosecute in military cases as is conferred on the public prosecutors.

It is proposed, furthermore, that the investigation of military criminal cases shall be conducted by a group of investigators from the military police, directly under the Director General of Military Prosecutions, with the prosecuting authority having the exclusive power to issue orders and impose instructions during the investigation.

Under the Committee's proposal, the court shall as a main rule not include military lay judges in military criminal cases. The need for expertise shall be assessed on the basis of the general statutory provision on the appointment of expert lay judges. It is proposed, furthermore, that the conduct of military criminal cases be centralised in selected courts. It is proposed that detailed provisions be laid down in the form of administrative regulations.

\subsubsection{Private criminal cases}

In Chapter 24, the Committee proposes to abolish the arrangement for private criminal cases. The main reasoning behind the proposal is that criminal prosecution should be a matter for the State. Criminal prosecution involves considerable responsibility, which should only be conferred on an independent and objective prosecuting authority. The range of sanctions available to the State should not be placed at the disposal of private parties. This position must be considered in the context of the observations made with regard to whether the aggrieved person should be accorded the status of party to criminal proceedings, cf. Sub-chapter 10.3.1. 
The specific need for private criminal prosecution seems limited, and the number of such cases before the Norwegian courts in recent years has been small. The practical scope of private prosecution has been focused, in particular, on defamation cases. Criminal liability for defamation was abolished when the new Penal Code entered into effect, and hence there is reason to assume that the number of private criminal cases will further decline.

The legitimate interest of the aggrieved person in presenting his or her view on the issue of prosecution is, in the opinion of the Committee, adequately catered for via the scope for appealing the prosecution decision. Furthermore, the prosecuting authority's handling of the case may be brought before the Parliamentary Ombudsman. As far as a potential claims for compensation are concerned, the interests of the aggrieved person are attended to via the scope for instituting civil proceedings pursuant to the Dispute Act. Moreover, the Committee's proposal calls for the superior prosecuting authority to specifically supervise, to a greater extent than at present, the subordinate prosecuting authority. It must be assumed that this will strengthen the quality of prosecution decisions, in addition to facilitating the correction of specific misjudgements. Criticism of the general prioritisations of the prosecuting authority should be communicated via the ordinary political channels.

\subsubsection{Monetary claims, etc. (Part 11 of the draft legislation)}

Chapter 25 contains the Committee's discussions of the scope for hearing civil claims in criminal cases (Chapter 43 of the draft legislation). The Committee is of the view that there should, as at present, be broad scope for hearing various claims alongside criminal claims. Joint hearing of claims delivers significant resource savings and relieves the aggrieved person with a claim for compensation of the burden of further proceedings. It is proposed to somewhat expand the arrangement by, inter alia, enabling administrative sanctions to be imposed in connection with criminal cases.

The current provisions on the hearing of civil claims in the context of criminal procedure are found in various chapters of the Criminal Procedure Act and are fairly complex in structure. The Committee has deemed it important to make the provisions more readily accessible, and has opted for bringing the provisions on civil claims together in one chapter.

The procedural provisions in the draft are more detailed than those in the current Criminal Procedure Act. The main rule shall, as at present, be that the provisions on the hearing of the criminal claims shall also regulate the hearing of the civil claims to the extent applicable. A new feature is that it is expressly stated that the proceedings shall take place within a basic framework moulded on the Dispute Act. 
There shall, under the Committee's proposal, to a greater extent than at present be imposed obligations on the claimholder when civil claims are heard in the context of criminal procedure. There shall, inter alia, be stipulated a time limit for filing a request for the hearing of civil claims. The main rule under the draft is that claims that have been served on the opposite party or submitted in a court hearing shall be deemed to have been waived if withdrawn from the proceedings before the court has ruled thereon. Such stricter requirements concerning the conduct of civil claims must be considered in view of the aggrieved person and surviving relatives largely being assisted in the conduct of such claims. Besides, the prosecuting authority has in the draft been given a duty to inform injured persons of the scope for hearing civil claims during criminal prosecution. All in all, this formal framework will presumably be conducive to more predictable - and thus more efficient - hearing of civil claims in criminal cases.

A significant difference from prevailing law is that the draft reintroduces the principle of uniformity. The principle, which underpinned the previous Criminal Procedure Act, implies that if someone is acquitted of a criminal claim, it shall not be permitted to adjudicate, in the same proceedings, civil claims originating from the same subject matter. The background to the Committee's recommendation in this regard is that there are different standards of proof and different requirements as to the preponderance of votes for criminal claims and civil claims, which for a joint hearing of claims implies that the indicted person may be acquitted of the criminal claim whilst at the same time being held liable for the same subject matter for civil law purposes. The Committee is of the view that such a divergent outcome in the same proceedings is problematic, because it undermines the acquittal in respect of the criminal claim. Besides, the hearing of civil claims following an acquittal in respect of the criminal claim will pose significant challenges, especially because it follows from Article 6(2) of the European Convention on Human Rights that the court cannot, in such a situation, formulate its conclusions in a manner that sows doubt about the innocence of the tortfeasor under criminal law. A principle of uniformity avoids these undesirable effects.

In order to safeguard the injured person against suffering a loss as the result of civil claims no longer being heard in the proceedings in the event of acquittal in respect of the criminal claim, the Committee is of the view that an arrangement should be introduced under which the State covers the claims of the aggrieved person for certain types of cases. It is proposed that such arrangement shall apply to cases in which the indictment concerns offences that represent a violation or attempted violation of 'life, health or liberty'. The prosecuting authority should determine whether the basis of liability falls within the scope of the indictment, and the level of compensation should be determined by the criminal injuries compensation authorities. Furthermore, the claim should be covered without taking a view on whether the acquitted person is guilty. Such an arrangement will, in addition to strengthening the presumption of innocence, normalise the protec- 
tion of the injured person from the perspective of the law of torts, since payment is not restricted by the stricter standard of proof otherwise applied in the hearing of civil claims that have their origin in criminal offences. Any claim falling outside the scope of the compensation scheme (guarantee scheme) may, in the event of acquittal, be brought before the courts in separate proceedings pursuant to the provisions of the Dispute Act.

In Chapter 26, the Committee discusses the issue of liability for legal costs (Chapter 44 of the draft legislation). The Committee is of the view that the state should, as a main rule, cover the expenses of conducting criminal cases. The limited scope of the suspect for influencing the proceedings, as well as social and structural legal considerations, all favour such a solution. The Committee is of the view, against this background, that the scope for holding the suspect liable for legal costs under prevailing law is broader than is desirable. The draft stipulates that the suspect may only be held liable for costs incurred in conducting criminal cases which are incurred as the result of him or her complicating the case.

Chapter 27 contains the Committee's discussion of the provisions on the right to compensation after criminal prosecution (Chapter 45 of the draft legislation). The current regulation is maintained in its predominant aspects, but modifications are made in some respects. The Committee is of the view that the provision in Section 446 of the Criminal Procedure Act on the reduction or elimination of compensation in the event of contributory acts is difficult to justify, and recommends that it be brought more into line with the principle in Section 5-1 of the Compensatory Damages Act. Furthermore, the Committee proposes, in view of the rationale behind the compensation scheme, a provision that limits the right to compensation for certain legal entities.

\subsubsection{Financial and administrative implications}

Chapter 28 addresses financial and administrative implications of the Committee's proposal.

\subsection{Comments on the Committee's legislative proposal (Part IV of the report)}

Chapter 29 provides an overview of the structure of the proposal for a new Criminal Procedure Act and its relationship to other parts of the regulatory framework. In Sub-chapter 29.1, the Committee outlines the reasoning behind its proposal that the title of the new act should be 'Act relating to the Conduct of Criminal Cases (the Criminal Procedure Act). Furthermore, the division of the act into parts and chapters is explained. Sub-chapter 29.2 addresses the relationship to, inter alia, the Dispute Act, the Courts of Justice Act, the Penal Code, the Execution of Sentences Act, the Police Records Act and the Prose- 
cution Instructions. The Committee's proposal will necessitate extensive consequential amendments to other parts of the regulatory framework, and there is reason to examine more closely whether, inter alia, the Dispute Act should be brought into conformity with the adopted regulations. The effort will have to be carried out at a later stage of the legislative process. Besides, it will be necessary to revise the Prosecution Instructions, and the Committee is presenting certain general recommendations for such revision.

Chapter 30 contains comments on the individual parts, chapters and provisions of the draft new Criminal Procedure Act, with explanation of the contents of the proposed changes. The relationship to prevailing law is in the comments largely limited to a reference to key provisions that are retained, and to discussions in the general observations. A listing of the relationship between individual provisions of the current act and the draft new act is attached as Appendix 1.

Chapter 31 contains the Committee's comments on proposed amendments to the Constitution and other statutes.

The Committee proposes to amend Article 96 of the Constitution to introduce a requirement for 'independent accusation'; see the discussion in Sub-chapter 8.5. The proposal must be considered in the context of the Committee's proposal for strengthening the independence of the prosecuting authority from political authorities in the draft new Criminal Procedure Act; see Sub-chapters 3.3.2 and 8.2.1, as well as the proposed abolition of the arrangement for private criminal cases; see Sub-chapter 3.3.12 and Chapter 24.

It is proposed to amend the Courts of Justice Act to introduce provisions on information security; see Sub-chapter 6.4.2.3, communication with the courts of justice; see Sub-chapter 6.4.3.2, electronic service of documents; see Sub-chapter 6.4.4.2, remote examination and remote hearing; see Sub-chapter 6.4.5.3, recording during court hearings; see Sub-chapter 6.5.3.3, and court hearings and court records; see Sub-chapter 29.2.3.

The Committee's proposal for provisions on international collaboration in Part 4 of the draft legislation will occasion amendments to the Extradition Act, the Courts of Justice Act, the Penal Code, Act of 15 June 2001 No. 65 relating to the Implementation in Norwegian law of the Statute of the International Criminal Court of 17 July 1998 (the Rome Statute) and Act of 24 June 1994 No. 38 relating to the Implementation in Norwegian law of United Nations Security Council Resolutions on the Establishment of International Tribunals for Crimes in the Former Yugoslavia and Rwanda. Moreover, it is proposed, as a result of the regulation in Part 4 of the draft, to repeal Act of 25 March 1977 No. 22 relating to the Transfer of Criminal Prosecution from or to other European Countries and Act of 13 June 1997 No. 47 on Implementation of the Council of Europe Agreement of 31 January 1995 on Illicit Traffic in Narcotic Drugs and Psychotropic Substances by Sea. See Sub-chapter 15.3 for further details. 
It is proposed that the authorisation for the Norwegian Correctional Services to make decisions, submit requests and attend court hearings under certain circumstances be moved to the Execution of Sentences Act; see Sub-chapter 8.2.5.2.

It is proposed that the duty of the child welfare service to inform the prosecuting authority of decisions in child welfare cases be regulated in the Child Welfare Act; see the comments on Section 28-2, Sub-section 3, of the draft and on the proposed amendment to Section 3-5 of the Child Welfare Act. 